\title{
Growth versus storage: responses of Mediterranean oak seedlings to changes in nutrient and water availabilities
}

\author{
Virginia SANZ PÉrEZ ${ }^{\text {a* }}$, Pilar CASTRo DíEZ ${ }^{\mathrm{a}}$, Fernando VALlADARES $^{\mathrm{b}}$ \\ a Departamento de Ecología, Universidad de Alcalá, Alcalá de Henares 28871 Madrid, Spain \\ ${ }^{\mathrm{b}}$ Instituto de Recursos Naturales, Centro de Ciencias Medioambientales, CSIC, Serrano 115, 28006 Madrid, Spain
}

(Received 31 March 2006; accepted 15 June 2006)

\begin{abstract}
We compare dry mass (DM) and storage of starch (St) and nitrogen $(\mathrm{N})$ in seedlings of three Mediterranean oaks, two evergreens (Quercus coccifera L. and $Q$. ilex L. subsp. ballota (Desf.) Samp) and one deciduous ( $Q$. faginea Lam.), across different scenarios of nutrient and water availabilities. Three fertilization (5, 50 and $200 \mathrm{mg}$ of $\mathrm{N}$ per plant and growing period) and watering (28-39, 55-71 and $70-85 \mathrm{~g} \mathrm{H}_{2} \mathrm{O}_{100 \mathrm{~g}_{\text {soil }}^{-1}}$ gravimetric soil water) treatments were applied to current-year seedlings between May and October 2002 in two independent experiments. The three species showed a similar response to fertilization, storing nitrogen instead of increasing biomass, in agreement with adaptations to nutrient-poor habitats. However, they differed in their responses to water, reflecting the different water requirements in the field: Q. coccifera, from arid zones, showed no response to water regarding DM and St; Q. faginea, from humid zones, required higher water availability to simultaneously increase growth and storage; while $Q$. ilex, spanning over most of the water availability range, exhibited a balanced increase of both functions when water increased moderately. In the two evergreen species, $\mathrm{N}$ concentration increased with water supply, whereas the reverse occurred in $Q$. faginea. The latter species favoured growth over storage at moderate water supply (according to its more competitive strategy), although it was the species which accumulated more St and $\mathrm{N}$ at the end of the experiments (autumn).
\end{abstract}

fertilization / N storage / seedling growth / starch storage / water stress

Résumé - Croissance par rapport au stockage : réponses de semis de chênes méditerranéens aux changements de nutrition et de disponibilité en eau. Nous avons comparé la masse sèche (DM) et le stockage d'amidon (St) et d'azote (N) chez des semis de chênes méditerranéens, deux à feuilles persistantes (Quercus coccifera L. et Quercus ilex L. subsp. Ballota (Desf.) Samp) et un à feuilles caduques (Q. faginea Lam.), pour différents scénarios de nutrition et de disponibilités en eau : trois niveaux de fertilisation $(5,50$ et $200 \mathrm{mg}$ d'azote par plant et période de croissance) et d'arrosage (28-39, 55-71 et 70-85 g H2O pour $100 \mathrm{~g}$ de sol). Ces traitements ont été appliqués l'année en cours des semis entre mai et octobre dans deux expérimentations indépendantes. Les trois espèces ont montré une réponse similaire à la fertilisation, stockant l'azote plutôt que d'accroître la biomasse, en accord avec les adaptations aux habitats ayant une nutrition pauvre. Cependant ils diffèrent dans leurs réponses à l'alimentation hydrique, reflétant leurs besoins différents en eau dans la nature : Quercus coccifera, venant des zones arides ne montre pas de réponse à l'alimentation hydrique pour ce qui concerne DM et $\mathrm{St} ; Q$. faginea, issu de zones humides, demande une disponibilité en eau plus importante pour simultanément croître et stocker, tandis que Quercus ilex, couvrant davantage l'étendue des possibilités de disponibilité en eau, présente un accroissement équilibré des deux fonctions lorsque l'alimentation en eau s'accroît modérément. Chez les deux espèces à feuilles persistantes, la concentration en azote s'accroît avec la fourniture d'eau, alors que l'inverse se produit chez $Q$. faginea. Cette dernière espèce favorise la croissance sur le stockage pour des apports en eau modérés (conformément à une meilleure stratégie de compétition), bien que cela soit l'espèce qui a accumulé le plus $\mathrm{N}$ et St à la fin des expérimentations (automne).

fertilisation / stockage d'azote / croissance des semis / stockage d'amidon / stress hydrique

\section{INTRODUCTION}

During the last decades extensive reforestations have been conducted by national forest services all over the Mediterranean region [41] and more recently, plantations of medium or late-succession native trees and shrubs are being promoted in spite of their poor outplanting performance [1]. Among forest species, initial seedling size or biomass has been related to post-planting survival [33], to the ability to outcompete other plant species [23] and to the potential for new root production [47], which is crucial to face the arid Mediterranean summer. In addition, carbohydrate reserves in form of starch

\footnotetext{
*Corresponding author: virginia.sanz@uah.es
}

provide an important carbon source for both resprouting after disturbance [22] and respiration during periods of resource shortage [31]. Moreover, soluble sugars may be involved in osmotic adjustment [16] as osmolites. Therefore, carbohydrate reserves may play an important role to face the major constraints posed by continental Mediterranean climate, i.e., summer drought and winter cold [30]. On the other hand, nitrogen storage affects the rate of growth after planting in the field [25] and seedling capacity to recover foliage after disturbances [4].

Seedling biomass, carbohydrates, and nitrogen storage may vary in response to resource availability but results are still inconclusive $[34,47]$. In addition, only few studies have addressed integrated response of biomass, carbohydrate and 
nitrogen storage to resource availability [40]. Growth and storage may compete for carbon and nitrogen [10,20], but environmental variations may alter the proportion at which both resources are captured and stored. Bryant et al. [6] tried to explain changes in carbon and nitrogen allocation to different plant functions in response to variations of the inner carbonnutrient balance (CNB hypothesis). This hypothesis relies on the fact that tissue growth demands quite a constant proportion of carbon and nitrogen. Therefore any factor decreasing the uptake of either carbon or nitrogen would limit plant growth and lead to an excess of the non-limiting element, which would be accumulated or diverted to the synthesis of nitrogen- or carbon-based secondary metabolites. Although the power of this hypothesis to predict accumulation of particular defensive compounds has been found to be low [18], the rationale can still be used to predict within-species responses to resources changes of whole-plant nitrogen and carbohydrates. In fact, literature provides several examples supporting CNB general predictions; for example, some authors have found that a high nutrient availability decreases starch concentration in favour of plant growth $[27,32]$ and increases nitrogen concentration $[5,35]$. However, when water is the main growth limiting factor, predictions about storage and allocation are less obvious $[7,20]$ as water stress limits both carbon and nitrogen gain [42].

The aim of the present study was to assess the combined response of growth, carbohydrate and nitrogen reserves of seedlings of three Mediterranean oaks (Quercus coccifera, $Q$. ilex subsp. ballota and $Q$. faginea) to changes in nutrient and water availabilities during their first-year of growth. We tested the following working hypotheses: (1) Under high nutrient availability, plant $\mathrm{C} / \mathrm{N}$ balance decreases and plant growth will be enhanced until being carbon-limited; in such circumstances, carbohydrate reserves will be low, while nitrogen will be in excess and therefore stored. (2) As water stress limits both carbon and nitrogen uptake $[42,44]$, larger water availability is expected to increase plant growth without altering plant $\mathrm{C} / \mathrm{N}$ balance. (3) Under higher resource availability, the fastest-growing species (i.e. $Q$. faginea [12]) will favour growth over storage more than the slow growing evergreen oaks ( $Q$. coccifera and $Q$. ilex).

\section{MATERIALS AND METHODS}

\subsection{Species}

We selected for the study three congeneric Mediterranean oak species, Quercus coccifera L., Q. ilex L. subsp. ballota (Desf.) Samp. and $Q$. faginea Lam. These species have a wide distribution range in the continental part of the Iberian peninsula but they differ in physiognomy and ecology. Q. coccifera is an evergreen shrub that lives in semi-arid regions and on degraded soils. Q. ilex subsp. ballota is the dominant tree in a large part of the inner Iberian Peninsula, supporting both low winter temperatures and summer drought [3]. $Q$. faginea is a deciduous/marcescent tree, although seedlings perform as evergreens; it lives under more mesic conditions than the other two species [9].

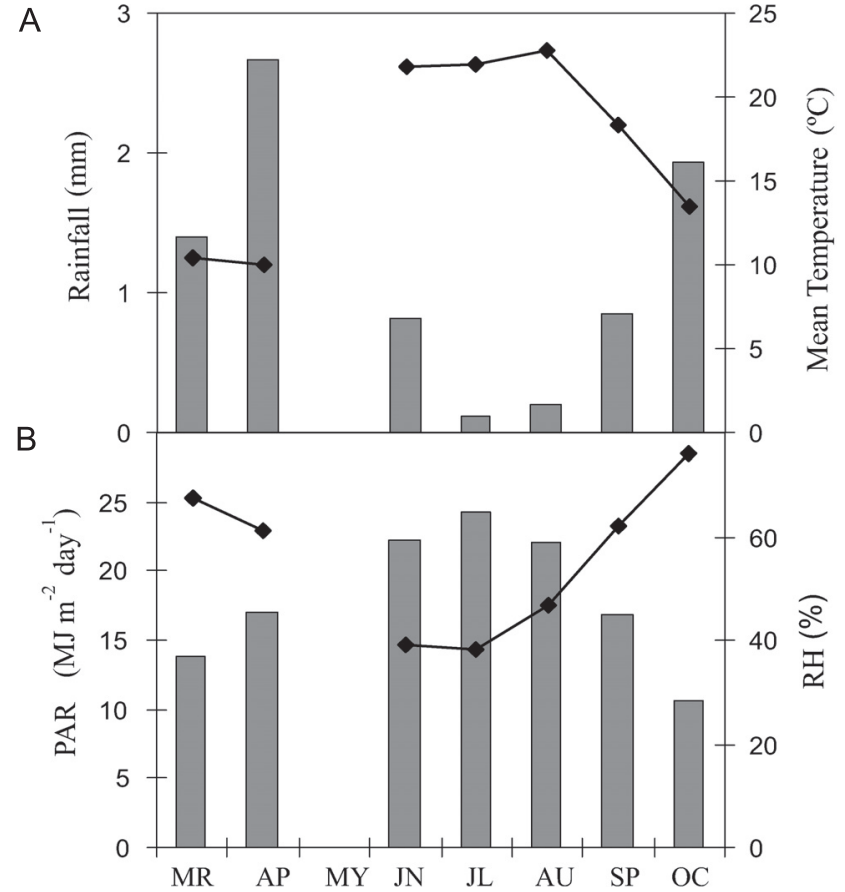

Figure 1. Microclimatic conditions during the experiment in the nursery. (A) Mean temperature (line) and precipitation (bars) and (B) air humidity (line) and photosynthetic active radiation (PAR) (bars). May values are missing.

\subsection{Experimental design}

The experiments were performed with first-year seedlings because this is the plant life stage when selective pressures are stronger [37] and because this is the period that forest seedlings spend in nurseries, where manipulation of resources is possible. Acorns of the three species were collected in October 2001 from two Spanish continental sites $(Q$. ilex and $Q$. faginea from Alcarria - Serranía de Cuenca forest region ES9 and Q. coccifera from Sistema Ibérico Meridional forest region RIU 25) and were sown at the end of March 2002 in Forest Pot 300 containers, which have 50 cavities of $300 \mathrm{~cm}^{3}$ filled with peat $(\mathrm{pH}=4)$ and vermiculite $(3: 1 \mathrm{v}: \mathrm{v})$. The containers were placed outdoors in the nursery of Centro de Capacitación Agraria TRAGSA in San Fernando de Henares (40 $24^{\prime}$ N, $3^{\circ} 29^{\prime}$ W), Madrid, Central Spain where the climate is typically continental Mediterranean (Fig. 1). Seedlings emerged by the end of April, and were regularly watered with no fertilizers till the second week of May 2002. Seedlings were maintained in the open all the time.

The treatments started in May 2002, when most seedlings had mature leaves, and ended in October 2002. Two independent trials were carried out, one with three contrasting levels of watering and the other with three levels of fertilization. In each experiment, four containers of 50 plants per species and treatment were used.

Local air temperature and photosynthetically active radiation (PAR) were registered every 5 min during the whole growing season with a data logger (HOBO model H08-006-04, Onset, Pocasset, MA, USA) and external sensors cross-calibrated with a Li-Cor 190SA sensor (Li-Cor, Nebraska, USA). Rainfall and relative humidity (RH) data were provided by the Meteorological Service of San Fernando de Henares, Madrid (Fig. 1). 


\subsubsection{Fertilization experiment}

Three levels of fertilization were established using Peters solution (N:P:K, 20:7:19): low (LF), moderate (MF), and high (HF), corresponding to a total amount of 5, 50 and $200 \mathrm{mg} \mathrm{N}$ per seedling, respectively. The nutrient solution was applied in an exponential way along the experiment period to adjust the supply to the increasing demands of growing plants $[11,43]$. All seedlings were grown with a moderate level of watering (see below).

\subsubsection{Water stress experiment}

Water was supplied with a rail irrigation system (Conic System) two, four and eight times per week, to get the low, moderate and high water levels (LW, MW, HW) respectively. The timing, frequency and duration of each watering were empirically adjusted throughout the seasons to obtain three distinct and relatively constant levels of water availabilities (Fig. 2). Five containers were randomly chosen from each treatment and were weighed periodically before and after the watering to monitor the gravimetric soil water, which was 28-39, 55-71 and 70-85 $\mathrm{g} \mathrm{H}_{2} \mathrm{O} 100 \mathrm{~g}_{\text {soil }}^{-1}$ for $\mathrm{LW}, \mathrm{MW}$ and $\mathrm{HW}$ respectively (Fig. 2). The gravimetric soil water at field capacity was $105 \mathrm{~g} \mathrm{H}_{2} \mathrm{O}$ $100 \mathrm{~g}_{\text {soil }}^{-1}$. A previous work has shown that a water treatment similar to our LW caused a high mortality to $Q$. ilex and $Q$. coccifera seedlings [45]. Even though all treatments started during the second week of May 2002, water availability could be well controlled only during the dry period (mid June till end of August). In the rest of the time of the experiment, random rainfall attenuated the differences between water treatments. All seedlings were grown with a moderate level of fertilization. Therefore, the MW-MF treatment was common to the two experiments.

\subsection{Growth measurements}

Ten seedlings per species and treatment were harvested at random at the end of the experiments (October). Seedlings were separated into leaves, stems and roots. Roots were gently washed to eliminate soil particles. All parts were oven-dried at $60{ }^{\circ} \mathrm{C}$ for $48 \mathrm{~h}$ and weighed separately.

\subsection{Chemical analysis}

In October 2002, five additional seedlings per species and treatment were harvested in the morning, separated into leaves, stems and roots and gently washed. All plant parts were introduced in liquid nitrogen for 2-4 h to stop their metabolic reactions, and transferred to a freezer at $-20{ }^{\circ} \mathrm{C}$ for storage. Then, the samples were oven-dried and grounded to $0.5 \mathrm{~mm}$ powder with a Culatti mill before analysis.

Total nitrogen $(\mathrm{N})$ and carbon $(\mathrm{C})$ content were measured with a $\mathrm{C} / \mathrm{N}$ analyser (Elementar Vario Max N/CN), and the $\mathrm{C} / \mathrm{N}$ ratio calculated. The concentration of soluble sugars (SS) and starch (St) were analysed as followed. Fifty mg of the sample powder were incubated $90 \mathrm{~min}$ in $100 \%$ ethanol at $80{ }^{\circ} \mathrm{C}$ to extract SS. Samples were then placed in a centrifuge at $13000 \mathrm{~g}$ for $5 \mathrm{~min}$ to separate the pellet containing St from the supernatant containing SS. The supernatant was dried for $48 \mathrm{~h}$ at $60{ }^{\circ} \mathrm{C}$, dissolved in distilled water and boiled for $5 \mathrm{~min}$. A $6 \mu \mathrm{L}$ aliquot from the re-hydrated sample was used to determine glucose content and an additional $300 \mu \mathrm{L}$ aliquot was used for

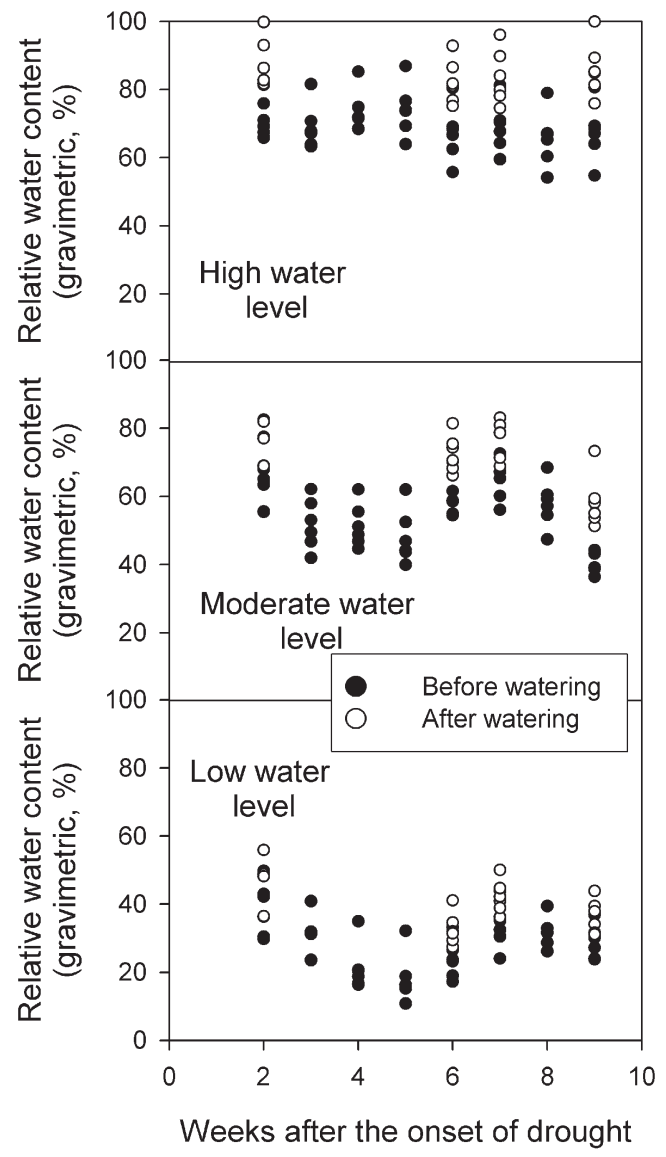

Figure 2. Time evolution of the gravimetric relative water content of five randomly selected containers before (closed symbols) and after (open symbols) the watering in the three water treatments. The treatments started in the second week of May 2002, but the graph represents water availability only during the dry period (mid June till end of August), when differences among treatments could be well controlled and exerted a significant influence on plant performance.

sucrose assessment. The latter was incubated with invertase (Sigma I4504) for $30 \mathrm{~min}$ at $55^{\circ} \mathrm{C}$ to break sucrose into monosacharids. The pellet was dried at $60^{\circ} \mathrm{C}$ during $24 \mathrm{~h}$, and incubated $16 \mathrm{~h}$ at $55^{\circ} \mathrm{C}$ with amyloglucosidase (Fluka, 10115) and $\alpha$-amylase (Fluka, 10065) in $0.1 \mathrm{M}$ phtalate buffer $(\mathrm{pH}=5)$ to break St into monosacharids. Then, St and SS samples were incubated for $5 \mathrm{~min}$ at $25^{\circ} \mathrm{C}$ with phosphoglucosidase isomerase Type II (PGI) (Sigma P-5381) to turn fructose into glucose. Finally, every aliquot was incubated at $37^{\circ} \mathrm{C}$ for $5 \mathrm{~min}$ with Infinitive Glucose Reagement (Sigma Diagnostics 17-25) and colorimetrically assessed measuring absorbance at $340 \mathrm{~nm}$ to obtain the glucose concentration. SS and St were expressed as mg per $\mathrm{g}$ of dry mass. Finally, total non structural carbohydrate content (TNC) was calculated as the sum of SS and St.

The total St pool per plant was calculated as:

$\mathrm{St}_{\text {pool }}=\mathrm{DM}_{\text {root }} \times[\mathrm{St}]_{\text {root }}+\mathrm{DM}_{\text {stem }} \times[\mathrm{St}]_{\text {stem }}+\mathrm{DM}_{\text {leaves }} \times[\mathrm{St}]_{\text {leaves }}$

$\mathrm{DM}_{\mathrm{x}}$ and $[\mathrm{St}]_{\mathrm{x}}$ being the dry mass and the St concentration of each plant part. We then calculated the average concentration for the whole plant ([St $\left.]_{\text {plant }}\right)$ as:

$$
[\mathrm{St}]_{\text {plant }}=\mathrm{St}_{\text {pool }} /\left(\mathrm{DM}_{\text {root }}+\mathrm{DM}_{\text {stem }}+\mathrm{DM}_{\text {leaves }}\right)
$$




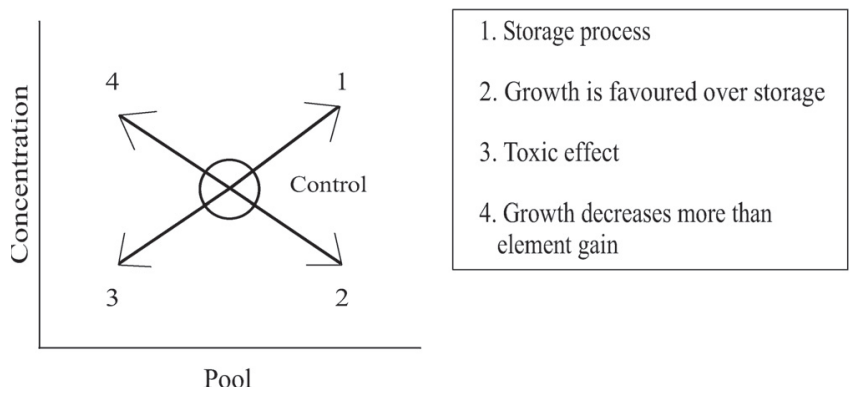

Figure 3. Hypothetical trajectories of starch or nitrogen pool and starch or nitrogen concentration described by plants in response to increases of resource availability. (See text for explanation.)

Total N pool per plant $\left(\mathrm{N}_{\text {pool }}\right)$ and whole-plant nitrogen concentration $\left([\mathrm{N}]_{\text {plant }}\right)$ were calculated following the same rationale.

\subsection{Data analysis}

Interpretation of changes in the concentration of any tissue compound across treatments may be misleading because it is affected both by changes in the pool of that compound and by changes in biomass. Therefore, in order to unravel $\mathrm{N}$ and carbohydrate trends across treatments, we represented whole-plant pool (X-axe) against wholeplant concentration (Y-axe) and drew the trajectory displayed by each species in response to the increase of water or nutrients $[32,39,43]$. Among carbohydrate compounds, we only selected St for this analysis because it is the main storage compound. Four theoretical trajectories are possible, as shown in Figure 3: (1) Both storage and growth are promoted, (2) growth is favoured over storage, (3) both storage and growth decline (toxic effect), and (4) growth is declined at a higher rate than the compound uptake, leading to an excess which is accumulated (luxury consumption). Trajectories implying no change in either concentration or pool, i.e., horizontal or vertical arrows, will be considered as intermediate between two of the above $(i, j)$ and named as trajectory $i-j$.

The effects of treatment and species on biomass, $\mathrm{C} / \mathrm{N}, \mathrm{N}$ and carbohydrate content of the whole-plant and each part were tested by means of a two-way analysis of variance (ANOVA). In addition, treatment effects on whole-plant traits were further analysed within each species using a one-way ANOVA. Differences between treatments in the same experiment were tested by post-hoc Bonferroni analysis. In some cases, variables were transformed to meet homocedasticity assumptions; however we failed to get this requisite for whole-plant $\mathrm{C} / \mathrm{N}$ in the fertilization experiment and $[\mathrm{N}]_{\text {plant }}$ in the watering one with the three species pooled, so in those cases we just perform oneway ANOVA. All statistics were performed using SPSS 12.0.

\section{RESULTS}

\subsection{Effects of fertilization}

Fertilization failed to increase $\mathrm{DM}_{\text {plant }}$ in all species, although $\mathrm{DM}_{\text {stem }}$ of $Q$. faginea was higher in MF and $\mathrm{HF}$ than in LF. (Tab. I, Fig. 4). However, fertilization reduced $\mathrm{C} / \mathrm{N}$ of

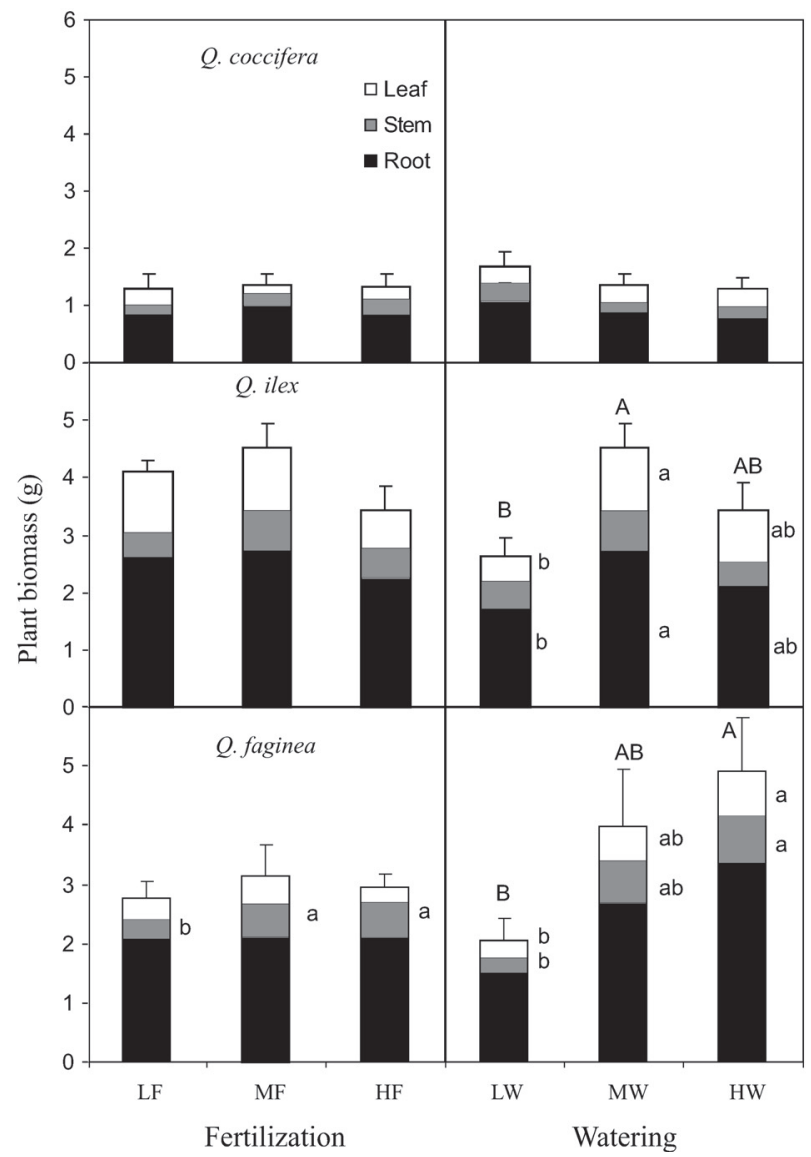

Figure 4. Final leaf, stem, root and whole-plant biomass in the fertilization (left) and watering (right) experiments. LF, MF and HF are low, moderate and high fertilization, respectively, and LW, MW and HW are low, moderate and high water treatment, respectively. Values are means of 15 plants. Error bars represent SE of whole-plant biomass. Different small and capital letters mean significant differences of plant organ biomass and whole-plant biomass among treatments, respectively (ANOVA, Bonferroni post-hoc, $P<0.05$ ).

the whole plant and each organ. The size of this effect varied across species, since the reduction of $\mathrm{C} / \mathrm{N}$ between $\mathrm{LF}$ and MF was larger in $Q$. coccifera than in the other species (Tab. I, Fig. 5). [SS] of the whole plant and each organ decreased with increasing fertilization, this effect being steeper in Q. ilex (Tabs. I and II). As St constituted the major fraction of TNC (data not shown), we therefore focused the description on St. Fertilization decreased $[\mathrm{St}]_{\text {plant }}$ and $[\mathrm{St}]_{\text {stem }}$ in all species; [St $]_{\text {plant }}$ was similar between LF and MF in the evergreens, while in the deciduous [St] $]_{\text {plant }}$ did not differ between MF and HF (Tab. I, Fig. 6). Whole-plant $\mathrm{St}_{\text {pool }}$ was only affected by fertilization in $Q$. ilex, being lower in HF than in the other two treatments (Fig. 6). Therefore, in response to added fertilization, St described a trajectory $2-3$ in $Q$. coccifera and Q. faginea, but a trajectory 3 in Q. ilex (Fig. 3).

Regarding nitrogen response, all species increased $[\mathrm{N}]$ of the whole plant and each fraction in response to fertilization, whereas $\mathrm{N}_{\text {pool }}$ only increased from LF to MF in $Q$. ilex and in 

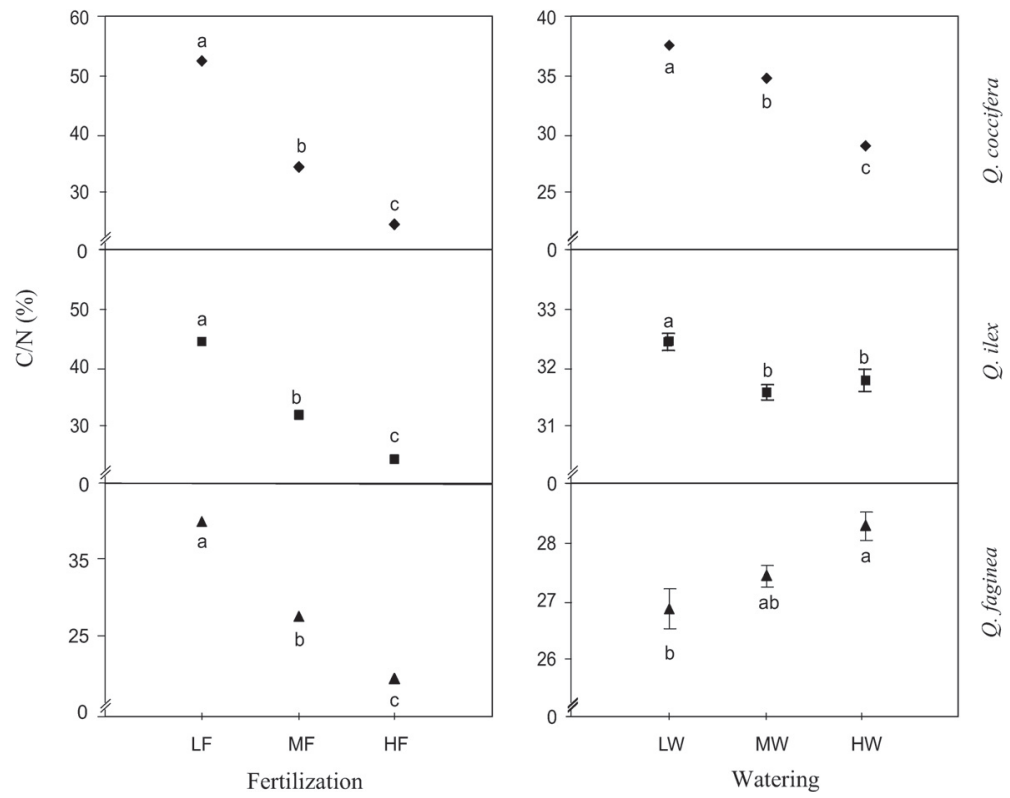

Figure 5. Effects of fertilization (left) and watering (right) on carbon-nitrogen ratio $(\mathrm{C} / \mathrm{N})$ in the whole plant. LF, MF and HF are low, moderate and high fertilization, respectively, and LW, MW and HW are low, moderate and high water treatment respectively. Values are means \pm SE $(n=5)$. Values with the same letter were not statistically different (ANOVA, Bonferroni post-hoc, $P<0.05$ ).

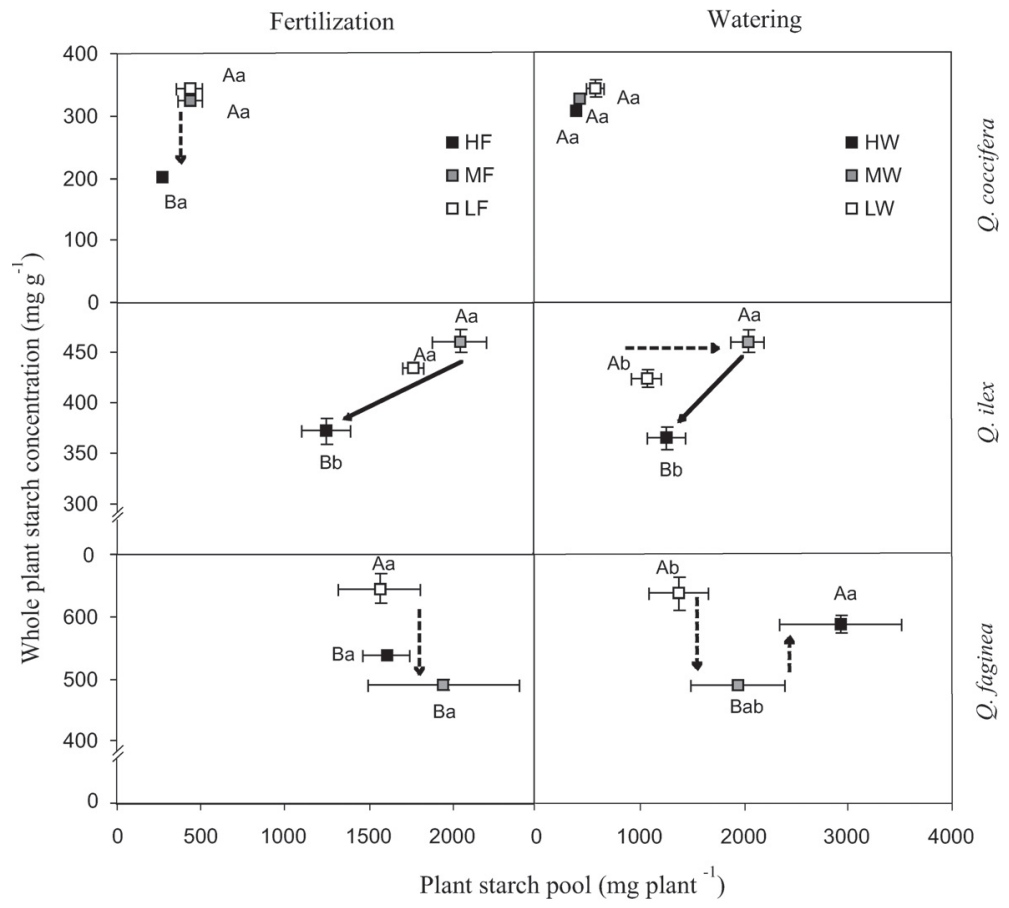

Figure 6. Effects of fertilization (left) and watering (right) on plant starch concentration (abscissas) and starch pool size (ordinates). LF, MF and HF are low, moderate and high fertilization, respectively, and LW, MW and HW are low, moderate and high water treatment, respectively. Different small and capital letters mean significant differences of starch pool and starch concentration among treatments, respectively. (ANOVA, Bonferroni post-hoc, $P<0.05$ ). Arrows indicate the trajectory between two treatments which differ statistically in one (broken arrow) or the two parameters (solid arrow). 
Table I. Summarised results of the two-way ANOVA testing the effect of fertilization and watering on the dry mass (DM), C/N ratio and the concentration of soluble sugars ([SS]), starch ([St]), total non structural carbohydrate ([TNC]) and nitrogen ([N]), in the whole plant and each plant fraction.

\begin{tabular}{|c|c|c|c|c|c|c|c|c|c|}
\hline \multirow[b]{2}{*}{ Variable } & \multirow[b]{2}{*}{ Factor } & \multicolumn{4}{|c|}{ Effect of fertilisation } & \multicolumn{4}{|c|}{ Effect of watering } \\
\hline & & Whole plant & Leaf & Stem & Root & Whole plant & Leaf & Stem & Root \\
\hline \multirow[t]{3}{*}{ Biomass } & Treatment & n.s. & $* *$ & n.s. & n.s. & $*$ & $*$ & $*$ & $* *$ \\
\hline & Specie & $* * *$ & $* * *$ & $* * *$ & $* * *$ & $* * *$ & $* * *$ & $* * *$ & $* * *$ \\
\hline & $\mathrm{T} \times \mathrm{S}$ & n.s. & n.s. & n.s. & n.s. & $* *$ & $* * *$ & $* *$ & $*$ \\
\hline \multirow[t]{3}{*}{$\mathrm{C} / \mathrm{N}$} & Treatment & & $* * *$ & $* * *$ & $* * *$ & $* * *$ & n.s. & n.s. & n.s. \\
\hline & Specie & & $* * *$ & $* * *$ & $* *$ & $* * *$ & $* * *$ & $* * *$ & n.s. \\
\hline & $\mathrm{T} \times \mathrm{S}$ & & n.s. & $* * *$ & n.s. & $* * *$ & n.s. & $* *$ & n.s. \\
\hline \multirow[t]{3}{*}{ [SS $]$} & Treatment & $* * *$ & $* *$ & $* * *$ & $* * *$ & $* * *$ & n.s. & $*$ & n.s. \\
\hline & Specie & $* * *$ & n.s. & $*$ & n.s. & $* * *$ & n.s. & $* *$ & n.s. \\
\hline & $\mathrm{T} \times \mathrm{S}$ & $* * *$ & n.s. & n.s. & n.s. & $* * *$ & n.s. & n.s. & n.s. \\
\hline \multirow[t]{3}{*}[\mathrm{St}]{} & Treatment & $* * *$ & n.s. & $*$ & n.s. & $* *$ & n.s. & $*$ & n.s. \\
\hline & Specie & $* * *$ & n.s. & $* *$ & $* * *$ & $* * *$ & n.s. & $* * *$ & $* * *$ \\
\hline & $\mathrm{T} \times \mathrm{S}$ & $* * *$ & n.s. & n.s. & n.s. & $* * *$ & n.s. & $* *$ & n.s. \\
\hline \multirow[t]{3}{*}{ [TNC] } & Treatment & $* * *$ & n.s. & $* *$ & n.s. & $* * *$ & n.s. & $* *$ & n.s. \\
\hline & Specie & $* * *$ & n.s. & $* * *$ & $* * *$ & $* * *$ & n.s. & $* * *$ & $* * *$ \\
\hline & $\mathrm{T} \times \mathrm{S}$ & $* * *$ & n.s. & n.s. & n.s. & $*$ & n.s. & $* *$ & n.s. \\
\hline \multirow[t]{3}{*}[\mathrm{N}]{} & Treatment & $* * *$ & $* * *$ & $* * *$ & $* * *$ & & n.s. & n.s. & n.s. \\
\hline & Specie & $* * *$ & $* * *$ & $* * *$ & $* *$ & & $* * *$ & $* * *$ & n.s. \\
\hline & $\mathrm{T} \times \mathrm{S}$ & n.s. & n.s. & n.s. & n.s. & & n.s. & $* *$ & n.s. \\
\hline
\end{tabular}

Table II. Mean values of $[\mathrm{SS}] \pm$ SE in the whole plant of $Q$. coccifera, $Q$. ilex and $Q$. faginea seedlings cultivated at different fertilization and watering conditions. Significance of the factors can be seen in Table I.

\begin{tabular}{lcccc}
\hline & & \multicolumn{3}{c}{ Resource of avaibility } \\
\cline { 3 - 5 } Fertilization & Q. coccifera & Low & Medium & High \\
& Q. ilex & $37.55 \pm 0.65$ & $33.37 \pm 0.54$ & $14.85 \pm 0.70$ \\
\multirow{3}{*}{ Watering } & Q. faginea & $40.50 \pm 0.16$ & $23.98 \pm 0.69$ & $10.70 \pm 0.59$ \\
& Q. coccifera & $50.25 \pm 1.08$ & $42.34 \pm 0.40$ & $23.26 \pm 0.56$ \\
& Q. ilex & $38.33 \pm 1.34$ & $27.70 \pm 0.35$ & $34.54 \pm 0.63$ \\
\hline
\end{tabular}

Q. faginea (Tab. I, Fig. 7). Therefore, trajectories of $\mathrm{N}$ were 4-1 in Q. coccifera and 1 in the remaining species (Fig. 3).

\subsection{Effects of watering}

The response of DM to watering differed across species (Tab. I). Q. coccifera did not respond; in contrast the ranking of whole-plant and each fraction's DM among treatments was $\mathrm{MW} \geqslant \mathrm{HW} \geqslant \mathrm{LW}$ for $Q$. ilex, and $\mathrm{HW} \geqslant \mathrm{MW} \geqslant \mathrm{LW}$ for Q. faginea (Fig. 4). Although, $\mathrm{C} / \mathrm{N}$ was unaffected by treatments in separate plant fractions, watering tended to decrease and to increase whole-plant $\mathrm{C} / \mathrm{N}$ in the two evergreens, and in $Q$. faginea, respectively (Tab. I, Fig. 5). $[\mathrm{SS}]_{\text {plant }}$ exhibited different trends with watering across species: while $Q$. coccifera and $Q$. faginea showed the highest values in $\mathrm{LW}, Q$. ilex did the same in MW. In contrast, the three species exhibited larger $[\mathrm{SS}]_{\text {stem }}$ in LW in all species (data not shown). Watering had similar effects on [St] and [TNC], therefore we only described St trends. [St $]_{\text {plant }}$ responded differently to watering across species (Tab. I): while Q. coccifera showed no response, $Q$. ilex exhibited similar $[\mathrm{St}]_{\text {plant }}$ between LW and MW that were larger than in HW. $Q$. faginea had the lowest value at MW whereas there was no difference between LW and HW (Fig. 6). $\mathrm{St}_{\text {pool }}$ was differently affected by watering in $Q$. ilex and $Q$. faginea, being higher at $\mathrm{MW}$ and at $\mathrm{HW}$ in the former and in the latter, respectively. Therefore, no species followed a clear $\mathrm{St}_{\text {pool- }}$ - $\left.\mathrm{St}\right]$ trajectory in response to an increase of water 


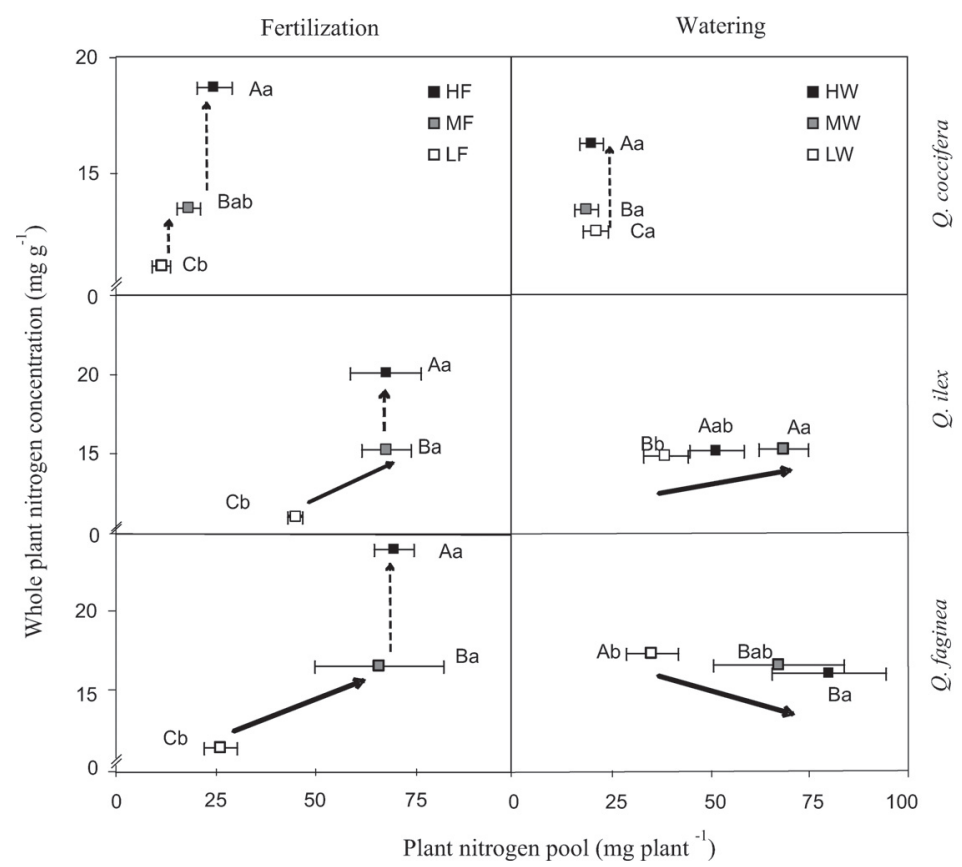

Figure 7. Effects of fertilization (left) and watering (right) on plant nitrogen concentration (abscissas) and nitrogen pool size (ordinates). Abbreviations and arrow meaning are the same as in Figure 6.

(Fig. 6). $[\mathrm{N}]_{\text {plant }}$ tended to increase with watering in the evergreens, the reverse being true for $Q$. faginea (Fig. 7). However, no plant fraction's [N] was affected by watering (Tab. I). $\mathrm{N}_{\text {pool }}$ of $Q$. coccifera was unaffected by watering while in the other species $\mathrm{N}_{\text {pool }}$ increased from LW to $\mathrm{HW}$ (Fig. 7). Thus, trajectories of $\mathrm{N}$ were $4-1$ in $Q$. coccifera, 1 in $Q$. ilex and 2 in Q. faginea.

\subsection{Effects of species}

The studied traits followed similar across-species trends at whole-plant level and at each plant organ level. Therefore, we just explain whole-plant trends. At the end of the experimental period $\mathrm{DM}_{\text {plant }}$ was the greatest in $Q$. ilex, followed by $Q$. faginea and by $Q$. coccifera (Fig. 4) under low resource levels. However, at higher supplies of either fertilization or watering, there was no $\mathrm{DM}_{\text {plant }}$ difference between the two trees (Fig. 4). Q. coccifera was the species with highest $\mathrm{C} / \mathrm{N}$ and this difference was greater at low levels of either fertilization or watering (Fig. 5). Q. faginea was the species that achieved higher [SS], [St], [TNC] and [N] in all treatments (Tabs. I and II, Figs. 6 and 7), although the cross-species contrast varied with the treatment level. In the case of [SS] across-species differences were larger in LW than in MW and HW (Tabs. I and II); in the case of [St] and [TNC], the lower contrast was found in MF and MW (Tab. I, Fig. 6).

\section{DISCUSSION}

\subsection{Effects of fertilization}

We expected high fertilization to increase both plant biomass and [N], and to decrease $\mathrm{C} / \mathrm{N}$ and [St] (hypothesis 1).
However, we found no effect on plant biomass although the latter three trends were observed. Our result suggests that seedling growth was not $\mathrm{N}$-limited in the LF treatment, as acorn reserves may account for seedling demands during the first year of growth [21], especially in Mediterranean slowgrowing species where nutrient demands are moderate [12]. Therefore, the addition of $\mathrm{N}$ external supply to young oak seedlings may promote luxury consumption $[39,43]$ and the accumulation of $\mathrm{N}$ in plant tissues for future use [10,15]. Cornelissen et al. [12] also found evidence of luxury nutrient consumption in 1-month-old seedlings of evergreen slowgrowing species, which, contrary to field-grown adults, did not exhibit lower leaf $\mathrm{N}$ concentration than fast-growing deciduous seedlings, grown under common non-limiting nutrient conditions. Therefore, the effects of fertilization are dependent on plant ontogeny and resource availability.

We expected the reduction of seedling [St] with fertilization to be a consequence of higher carbon consumption by growth (hyptothesis 1), but the lack of DM responses invalidated this reasoning. Other authors have found that fertilization promoted carbon allocation to the synthesis of amino acids and proteins $[13,31]$ and to support root respiration required for $\mathrm{N}$ uptake $[4,19]$, which may decline the synthesis of TNC.

The above fertilization-induced traits may have different implications for the future performance of seedlings in the field. On the one hand increased $\mathrm{N}$ could allow faster growth after transplanting. Indeed, it is known that $\mathrm{N}$ storage allows faster subsequent growth $[25,40]$ and improves ability to recover from defoliating disturbances [4]. On the other hand, the lower St reserves of HF seedlings would decrease their 
capacity to survive long stress periods or to recover from disturbances, which rely on stored carbon $[4,10]$.

\subsection{Effects of watering}

Irrigation induced contrasting growth and accumulation responses among the studied species. Predictions of hypothesis 2 on plant growth were only supported by $Q$. faginea, whose DM clearly increased with watering. The lack of response of Q. coccifera's DM accords with the low plasticity reported for this species by other authors $[7,45]$, but may also be attributed to LW being not stressful enough for this species. The low tolerance of $Q$. ilex to flooding [38] may explain that this species achieved the largest DM in moderate levels of water availability.

No species supported the expected lack of watering effect on $\mathrm{C} / \mathrm{N}$, as this trait decreased and increased with watering in the evergreens and in the deciduous species, respectively. This suggests that $\mathrm{C}$ and $\mathrm{N}$ uptake increases with watering at different rates. This may be attributed to differences of stomatal conductance among species at high water supplies, which was reported to be higher in $Q$. faginea than in $Q$. ilex [28], and similar between $Q$. ilex and $Q$. coccifera [26]. Thus, the rate at which $\mathrm{C}$ uptake increased with increasing water supply might be more limited by stomatal conductance in the evergreens than in the deciduous species. The $\mathrm{C} / \mathrm{N}$ decline promoted by watering in the two evergreens was accompanied by an increase of $[\mathrm{N}]$, suggesting that higher water supply induces $\mathrm{N}$ luxury consumption. The [St] decline shown by Q. ilex between MW and HW was not accompanied by significant changes of DM. Therefore, this St response may be explained by an increase of $\mathrm{C}$ demand for tissue respiration under the stressful conditions that higher water supplies apparently imposed to $Q$. ilex [10]. Regarding $Q$. faginea, the increased of $\mathrm{C} / \mathrm{N}$ with watering was paralleled by $[\mathrm{N}]$ decline and by $\mathrm{N}_{\text {pool }}$ increase, showing that a larger proportion the plant $\mathrm{N}_{\text {pool }}$ was consumed by growth to the detriment of accumulation. Although [St] also declined from LW to MW, it increased again from $\mathrm{MW}$ to $\mathrm{HW}$, suggesting that $\mathrm{C}$ gain at HW exceeded the amount required by growth, being accumulated for future use.

Due to their effects on DM and St, MW and HW would enhance the competitive ability [23], and would improve the capacity to keep a positive carbon balance after disturbances or stresses [22,31], in $Q$. ilex and $Q$. faginea, respectively. However, the increase of biomass in $Q$. faginea promoted by high watering supplies was to the detriment of $\mathrm{N}$ storage, what would have a negative effect on the leaf recovery capacity after defoliation.

\subsection{Species responses}

Hypothesis 3 predicted that $Q$. faginea would give higher priority to growth than to storage at high resource supplies. Our results support this hypothesis only for $\mathrm{N}$ responses in the water experiment, where $Q$. faginea was the species with higher DM increase and with lower $[\mathrm{N}]$ increase (this trait even declined between LF and MF) in response to watering. These responses accord with the more competitive strategy described for deciduous than for these evergreen Mediterranean trees $[8,46]$. Nevertheless, $Q$. faginea was, in general, the species with largest $\mathrm{St}$ and $\mathrm{N}$ reserves. This trend was partly accounted for by the larger proportion of root biomass exhibited by this species, which was the main St and $\mathrm{N}$ storage organ $[10,31]$. Additionally, deciduous species exhibit the greatest concentrations of St at the beginning of autumn [2], coinciding with the date of harvest in our study, while evergreens do so at the end of winter, just before bud break [14]. In the case of $\mathrm{N}$, the larger leaf $[\mathrm{N}]$ of $Q$. faginea reflects the higher proportion of $\mathrm{N}$-rich tissues in deciduous leaves as compared with evergreen ones, already reported in species comparisons in different ecosystems $[8,36]$. In contrast, the evergreen species, especially $Q$. coccifera, showed higher $\mathrm{C} / \mathrm{N}$ ratios, reflecting a greater proportion of structural carbon in plant tissues. This allocation pattern reflects an adaptation to stressful environments, where defensive and resistance traits may have been selected for, rather than productivity [17].

The two evergreen species allocated to leaves a greater proportion of their total $\mathrm{N}$ and St pools than the deciduous species, which did so in permanent organs (data not shown). This is in accordance with the storage function reported for evergreen leaves [24]. Thus, disturbances eliminating leaf biomass, would make the recovery of foliage to be slower in the evergreen species than in the deciduous one [29].

\section{CONCLUSIONS}

The three species showed a similar response to fertilization, storing nitrogen instead of increasing biomass, in agreement with adaptations to nutrient-poor habitats. However, high nutrient availability decreased starch reserves in all species, which may have a negative effect on their resprouting ability. Regarding watering, the two evergreen species showed the lowest $\mathrm{C} / \mathrm{N}$ under high water availability while the reverse occurred in the deciduous one. The growth-storage responses to water reflected the different water requirements of the species ( $Q$. coccifera from arid-zones, $Q$. faginea from humid zones and $Q$. ilex spanning over most of the range): $Q$. coccifera showed little response to water, $Q$. ilex exhibited a balanced increase of growth and storage when water increased moderately, and $Q$. faginea required higher water availability to simultaneously increase both functions. The conditions that represent the best compromise between growth and storage differ across similar and closely related species in accordance to their specific resource-use strategy.

Acknowledgements: We are very grateful to Inmaculada Santos and Daniela Brites for their work in the nursery. We also thank Melchor Maestro, Silvia Matesanz, Iker Dobarro, Elena Beamonte and Jorge González for assitance in different parts of the experiments. We wish to thank two anonymous referees, Dr. P. Villar, Dr. Ruben Milla, Oscar Godoy and Lucia Gálvez for their helpful suggestions. Financial support was provided by two grants of the Spanish Ministry of Education and Science (ECOFIARB, REN2000-0163-P4, and RASINV, CGL2004-04884-C02-02/BOS and AGL2004-00536/FOR). Virginia Sanz is supported by a grant from the Comunidad de Castilla - La Mancha. 


\section{REFERENCES}

[1] Baeza M.J., Pastor A., Martín J., Ibáñez M., Mortalidad postimplantación en repoblaciones de Pinus halepensis, Quercus ilex, Ceratonia siliqua y Tetraclinis articulata en la provincia de Alicante, Stvdia Oecologica 8 (1991) 139-146.

[2] Barbaroux D., Breda N., Dufrene E., Distribution of aboveground and below-ground carbohydrate reserves in adult trees of two contrasting broad-leaved species (Quercus petraea and Fagus sylvatica), New Phytol. 157 (2003) 605-615.

[3] Barbero M., Loisel R., Quézel P., Biogeography, ecology and history of Mediterranean Quercus ilex ecosystems, Vegetatio 99-100 (1992) 19-34.

[4] Bloom A.J., Chapin F.S. III, Mooney H.A., Resource limitation in plants - an economic analogy, Ann. Rev. Ecol. Syst. 16 (1985) 363392.

[5] Boivin J.R., Salifu K.F., Timmer V.R., Late-season fertilization of Picea mariana seedlings: intensive loading and outplanting response on greenhouse bioassays, Ann. For. Sci. 61 (2004) 737-745.

[6] Bryan J.P., Chapin F.S. III, Klein D.R., Carbon nutrient balance of boreal plants in relation to vertebrate herbivory, Oikos 40 (1983) 357-368.

[7] Castro Díez P., Navarro J., Pintado A., Sancho L.G., Maestro M., Interactive effects of shade and irrigation on the performance of seedlings of three Mediterranean Quercus species, Tree Physiol. 26 (2006) 389-400.

[8] Castro Díez P., Villar Salvador P., Pérez Rontomé C., Maestro M., Montserrat G., Leaf morphology and leaf chemical composition in three Quercus (Fagaceae) species along a rainfall gradient in NE Spain, Trees 11 (1997) 127-134.

[9] Castroviejo S., Laínz M., López Gonzalez G., Monserrat P., Muñoz Garmendia F., Paiva J., Villar L., Flora ibérica. Plantas vasculares de la Península Ibérica e Islas Baleares. Real Jardín Botánico, C.S.I.C., 1990.

[10] Chapin F.S. III, Schulze E.D., Mooney H.A., The ecology and economics of storage in plants, Ann. Rev. Ecol. Syst. 21 (1990) 423 447.

[11] Close D.C., Bail I., Hunter S., Beadle C.L., Effects of exponential nutrient-loading on morphological and nitrogen characteristics and on after-planting performance of Eucalyptus globulus seedlings, For. Ecol. Manage. 205 (2005) 397-403.

[12] Cornelissen J.H.C., Castro-Díez P., Hunt R., Seedling growth, allocation and leaf attributes in a wide range of woody plant species and types, J. Ecol. 84 (1996) 755-765.

[13] Cry D.R., Bewley J.D., Carbon and nitrogen reserves of leafy spurge (Euphorbia esula) roots as related to over wintering strategy, Physiol. Plant. 77 (1989) 67-72.

[14] Egger B., Eining W., Schlereth A., Wallenda T., Magel E., Loewe A., Hampp R., Carbohydrate metabolism in one and two year spruce needles, and stem carbohydrates from three months before until three months after bud break, Physiol. Plant. 96 (1996) 91-100.

[15] El-Omari B., Aranda X., Verdaguer D., Pascual G., Fleck I., Resource remobilization in Quercus ilex L. resprouts, Plant Soil 252 (2003) 349-357.

[16] Epron D., Dreyer E., Starch and soluble carbohydrates in leaves of water-stressed oak saplings, Ann. Sci. For. 53 (1996) 263-268.

[17] Grime J.P., Evidence for the existence of three primary strategies in plants and its relevance to ecological and evolutionary theory, Am. Nat. 111 (1977) 1169-1194.

[18] Hamilton J.G., Zangerl A.R., DeLucia E.H., Berenbaum M.R., The carbon-nutrient balance hypothesis: its rise and fall, Ecol. Lett. 4 (2001) 86-95.

[19] Henry L.T., Raper D.J., Soluble carbohydrates allocation to roots, photosynthetic rate of leaves, and nitrate assimilation as affected by nitrogen stress and irradiance, Bot. Gaz. 152 (1991) 23-33.
[20] Herms D.A., Mattson W.J., The dilemma of plants: to growth or defend, Q. Rev. Biol. 67 (1992) 283-335.

[21] Hewitt N., Seed size and shade-tolerance: A comparative analysis of North American temperate trees, Oecologia 114 (1998) 432-440.

[22] Huddle J.S., Pallardy S.G., Effect of fire on survival and growth of Acer rubrum and Quercus seedlings, For. Ecol. Manage. 118 (1999) $49-56$.

[23] Jobidon R., Roy V., Cyr G., Net effect of competing vegetation on selected environmental conditions and performance of four spruce seedling stock sizes after eight years in Québec (Canada), Ann. For. Sci. 60 (2003) 691-699.

[24] Legaz F., Serna M.D., Primo-Millo E., Mobilization of the reserve $\mathrm{N}$ in citrus, Plant Soil 173 (1995) 205-210.

[25] Malik V., Timmer V.R., Biomass partitioning and nitrogen retranslocation in black spruce seedlings on competitive mixedwood sites: a bioassay study, Can. J. Bot. 26 (1998) 1651-1659.

[26] Martinez-Ferri E., Balaguer L., Valladares F., Chico J.M., Energy dissipation in drought-avoiding and drought-tolerant tree species at midday during the Mediterranean summer, Tree Physiol. 20 (2000) 131-138.

[27] McDonald A.J.S., Ericsson A., Lohammar T., Dependence of starch storage on nutrient availability and photon flux density in small birch Betula pendula Roth, Plant Cell Environ. 9 (1986) 433-438.

[28] Mediavilla S., Escudero A., Stomatal responses to drought of mature trees and seedlings of two co-occurring Mediterranean oaks, For. Ecol. Manage. 187 (2004) 281-294.

[29] Millard P., Hester A., Wendler R., Baillie G., Interspecific defoliation responses of trees depend on sites of winter nitrogen storage, Funct. Ecol. 15 (2001) 535-543.

[30] Mitrakos K., A theory for Mediterranean plant life, Acta Oecol. 15 (1980) 245-252.

[31] Mooney H.A., The Carbon balance of plants, Ann. Rev. Ecol. Syst. 3 (1972) 315-346.

[32] Mooney H.A., Fichtner K., Schulze E.D., Growth, photosynthesis and storage of carbohydrates and nitrogen in Phaseolus lunatus in relation to resource availability, Oecologia 104 (1995) 17-23.

[33] Oliet J., Planelles R., López Arias M., Artero F., Efecto de la fertilización en vivero sobre la supervivencia en plantación de Pinus halepensis, Cuad. Soc. Esp. Cien. For. 4 (1997) 69-79.

[34] O'Reilli C., Owens M.K., Arnott J.T., Dunsworth B.G., Effects of nursery culture on morphological development of western hemlock seedlings during field establishment: I. Flushing, shoot elongation and bud development. II. Survival, shoot length components and needle length, Can. J. For. Res. 24 (1994) 53-70.

[35] Qu L., Quoreshi A.M., Koike T., Root growth characteristics, biomass and nutrient dynamics of seedlings of two larch species raised under different fertilization regimes, Plant Soil 255 (2003) 293-302.

[36] Reich P.B., Walters M.B., Ellsworth D.S., Leaf life-span in relation to leaf, plant and stand characteristics among diverse ecosystems, Ecol. Monogr. 62 (1992) 365-392.

[37] Reich P.B., Wright I.J., Cavender-Bares J., Craine J., Oleksyn J., Westoby M., Walters M.B., The evolution of plant functional variation: traits, spectra and strategies, Int. J. Plant Sci. 164 (2003) S143S164.

[38] Robin C., Capron G., Desprez-Loustau M.L., Root infection by Phytophthora cinnamomi in seedlings of three oak species, Plant Pathol. 50 (2001) 708-716.

[39] Salifu K.F., Jacobs D.F., Characterizing fertility targets and multielement interactions in nursery culture of Quercus rubra seedlings, Ann. For. Sci. 63 (2006) 231-237.

[40] Salifu K.F., Timmer V.R., Nitrogen retranslocation response of young Picea mariana to nitrogen-15 supply, Soil Sci. Soc. Am. J. 67 (2003) 1287-1294. 
41] Scarascia-Mugnozza G., Oswald H., Piussi P., Radoglou K., Forest of the Mediterranean region: gaps in knowledge and research needs, For. Ecol. Manage. 132 (2000) 97-109.

[42] Singh B., Singh G., Effects of controlled irrigation on water potential, nitrogen uptake and biomass production in Dalbergia sissoo seedlings, Environ. Exp. Bot. 55 (2006) 209-219.

[43] Timmer V.R., Aidelbaum A.S., Manual for exponential nutrient loading of seedlings to improve outplanting performance on competitive forest sites, Natural Resources Canada, Canadian Forest Service, Ontario, Canada, 1996.

[44] Timmer V.R., Miller B.D., Effects of contrasting fertilization and moisture regimes on biomass, nutrients, and water relations of container grown red pine seedlings, New For. 5 (1991) 335-348.
[45] Valladares F., Dobarro I., Sánchez-Gómez D., Pearcy R.W. Photoinhibition and drought in Mediterranean woody saplings: scaling effects and interactions in sun and shade phenotypes, J. Exp. Bot. 56 (2005) 483-494.

[46] Villar Salvador P., Castro Díez P., Pérez Rontomé C., Montserrat G., Stem xylem features in three Quercus (Fagaceae) species along a climatic gradient in NE Spain, Trees 12 (1997) 90-96.

[47] Villar Salvador P., Planelles R., Enríquez E., Peñuelas-Rubira J.L. Nursery cultivation regimes, plant functional attributes, and field performance relationships in the Mediterranean oak Quercus ilex L., For. Ecol. Manage. 196 (2004) 257-266. 